\title{
IMPLEMENTASI ADAPTASI KEBIASAAN BARU SELAMA ERA NEW NORMAL MELALUI TERAPI BERMAIN PADA ANAK USIA SEKOLAH
}

\author{
Riska Hediya Putri ${ }^{1 *}$, Feri Kameliawati ${ }^{2}$, Surmiasih ${ }^{2}$, Inggit Primadevi ${ }^{3}$ \\ ${ }^{1}$ Prodi Profesi Ners Universitas Aisyah Pringsewu \\ 2 Prodi S1 Keperawatan Universitas Aisyah Pringsewu \\ ${ }^{3}$ Prodi $\mathrm{S} 1$ Kebidanan Universitas Aisyah Pringsewu \\ Email korespondensi: riskahediya17@gmail.com
}

Disubmit: 23 Agustus 2021 Diterima: 23 Desember 2021

Diterbitkan: 02 Januari 2022

DOI: https://doi.org/10.33024/jkpm.v1i1.4884

\begin{abstract}
ABSTRAK
Pandemi Coronavirus Disease 2019 (COVID-19) mewabah ke seluruh dunia sejak awal tahun 2020 dan membawa dampak yang signifikan bagi kehidupan manusia di seluruh dunia. Wilayah di tanah air memberlakukan PSBB (Pembatasan Sosial Berskala Besar) yang menyebabkan sekolah dan tempat kerja diliburkan, kegiatan keagamaan atau ibadah bersama dibatasi dan kegiatan-kegiatan di tempat umum atau fasilitas publik juga dibatasi. Menilik himbauan dari pemerintah agar masyarakat tetap tinggal di rumah dan menjaga jarak sosial atau social distancing yang saat ini istilahnya diubah menjadi physical distancing oleh WHO. Physical distancing adalah hal yang hampir tidak mungkin dilakuakan oleh anak usia dini sebab dunia anak adalah dunia bermain dengan kecenderungan anak untuk berinteraksi secara langsung. Metode kegiatan pengabdian masyarakat ini dilakukan dengan terapi bermain ular tangga. Tujuan kegiatan ini memberi pengertian kepada anak tentang adaptasi kebiasan baru melalui cara yang menyenangkan, salah satunya melalui terapi bermain. Perbedaan pengetahuan anak sebelum dan sesudah kegiatan pendidikan kesehatan dengan media bermain ular tangga dan lebih berpengaruh dalam peningkatan pengetahuan dan sikap anak mengenai $3 \mathrm{M}$, terutama pada pertanyaan tanda dan gejala corona virus dan penting tidaknya memakai masker, adanya peningkatan presentasi sekitar $67 \%$. Oleh karena itu terapi bermain ular tangga lebih banyak memberikan rangsangan terhadap anak dan sesuai dengan keinginan anak yakni bermain.
\end{abstract}

Kata Kunci: Covid-19, New Normal, Terapi Bermain

\section{ABSTRACT}

Coronavirus Disease Pandemic 2019 (COVID-19) has spread to the world since the beginning of 2020 and has had a significant impact on human life around the world. Areas in the country impose PSBB (Pembatasan Sosial Berskala Besar) that cause schools and workplaces to be closed, religious activities or worship together are restricted and activities in public places or public facilities are also restricted. Considering the appeal from the government for people to stay at home and maintain social distance or social distancing which is currently the term changed to physical distancing by WHO. Physical distancing is almost impossible for early childhood to do because the world of children is a world of play with a tendency for children to interact directly. This method of community 
service activities is done with therapy playing snake ladder. The purpose of this activity gives understanding to children about the adaptation of new habits through fun ways, one of which is through play therapy. Differences in children's knowledge before and after health education activities with the medium of playing snake ladder and more influential in increasing the child's knowledge and attitude about $3 \mathrm{M}$, especially on the question of signs and symptoms of corona virus and the importance of not wearing a mask, there was an increase in presentation of about $67 \%$. Therefore, the therapy of playing snakes stairs provides more stimulation to the child and in accordance with the child's wishes, namely play.

Keywords: Covid-19, New Normal, Play Therapy

\section{PENDAHULUAN}

Novel coronavirus, yang juga disebut dengan SARS-CoV-2 (Severe Acute Respiratory Coronavirus 2) berawal dari Wuhan, Provinsi Hube, Cina, dan World Health Organization (WHO) telah menetapkan Coronavirus Disease 2019 (COVID19) sebagai ditetapkan sebagai pandemi global (Zeegen, Yates \& Jevsevar, 2020). Pandemi Coronavirus Disease 2019 (COVID-19) mewabah ke seluruh dunia sejak awal tahun 2020 dan membawa dampak yang signifikan bagi kehidupan manusia di seluruh dunia.

Pertanggal 26 September 2020, kasus covid-19 di dunia yang sudah terkonfirmasi mencapai 32.429.965 dengan 985.823 kasus meninggal dunia (WHO, 2020). Sedangkan data di Indonesai mencapai 271.339 kasus, dengan 10.308 kasus kemastian. Data di Provinsi Lampung sendiri mencapai 826 kasus terkonfirmasi dengan 30 kasus meninggal dunia. Kabupaten Pringsewu yang sebelumnya berada pada zona hijau (tidak ada kasus baru), pertanggal 8 September 2020 mengalami pertambahan kasus menjadi 17 kasus terkonfirmasi, hal ini pun mengakibatkan perubahan zona menjadi zona orange (resiko kenaikan kasus sedang (Dinas Kesehatan Provinsi Lampung, 2020).

Sejak dikeluarkannya PP Nomor 21 Tahun 2020 tentang Pembatasan Sosial Berskala Besar Dalam Rangka Percepatan Penanganan Corona Virus Disease (COVID-19) pada tanggal 31 Maret 2020, beberapa wilayah di tanah air memberlakukan PSBB (Pembatasan Sosial Berskala Besar) yang menyebabkan sekolah dan tempat kerja diliburkan, kegiatan keagamaan atau ibadah bersama dibatasi dan kegiatan-kegiatan di tempat umum atau fasilitas publik juga dibatasi. Hal ini untuk menghindari terjadinya kerumunan banyak orang agar resiko penularan virus ini dapat ditekan.

Dengan munculnya kebijakan PSBB tersebut akan memunculkan dampak yang signifikan terhadap kehidupan sosial masyarakat dan juga pada lini pendidikan. Mulai dari pergeseran budaya jabat tangan, berkumpul, pembelajaran hingga bertatap muka sekalipun. Adanya perubahan pada tatanan life style ini mempersiapkan masyarakat pada bentuk gaya hidup baru yang dikenal dengan istilah new normal (Saputra \& Muharammah, 2020). Indonesia sudab bersiap untuk memasuki era "New Normal" dimana orang dapat beraktivitas di luar rumah selama masa pandemic COVID-19. Hal ini merupakan salah satu cara beradaptasi ditengah kondisi pandemi, selama vaksin dan obatnya belum ditemukan. Mulai bulan Juni 2020 Indonesia sudah New Normal. Pengertian New Normal adalah melakukan aktivitas seperti kehidupan pada umumnya namun tetap memperhatikan protokal kesehatan. Covid-19 yang terjadi saat ini mau tidak mau memberikan dampak terhadap berbagai sektor (Pakpahan, 2020). Salah satu 
sektor yang terkena dampak virus ini adalah sektor pendidikan. Dimana proses pembelajaran dilakukan secara daring yang menyebabkan anak-anak belajar dari rumah.

Covid-19 yang terjadi saat ini mau tidak mau memberikan dampak terhadap berbagai sector. Salah satu sektor yang terkena dampak virus ini adalah sektor pendidikan. Dimana proses pembelajaran dilakukan secara daring yang menyebabkan anak-anak belajar dari rumah. Menilik himbauan dari pemerintah agar masyarakat tetap tinggal di rumah dan menjaga jarak sosial atau social distancing yang saat ini istilahnya diubah menjadi physical distancing oleh WHO. Physical distancing adalah hal yang hampir tidak mungkin dilakuakan oleh anak usia dini sebab dunia anak adalah dunia bermain dengan kecenderungan anak untuk berinteraksi secara langsung. Baik bersama teman sebaya ataupun orang dewasa dan kenyataan yang tak bisa dinafikkan adalah anak-anak masih berada dibawah kekuasaan orang dewasa yang artinya dalam melakuakan sesuatu mereka masih membutuhkan peran orang dewasa baik untuk mengawasi ataupun membantunya. Boleh jadi orang tua membatasi anak agar bermain di rumah tapi bukan berarti anak akan merasa terkekang. Pada daerah perkotaan yang khas dengan indivudualisme bisa jadi anak sudah terbiasa untuk bermain sendiri di dalam rumah maka secara jelas \#dirumahaja adalah kebiasaan mereka seharihari.

Namun pada daerah tertentu yang lekat dengan riuhnya anak-anak berkumpul untuk bermain bersama baik di beranda rumah, lapangan, kebun ataupun disekitar jalanan gang, pada kondisi ini hampir bisa dipastikan physical distancing adalah hal yang tidak mungkin bagi mereka. Dengan bisa atau tidaknya anak untuk melakukan physical distancing sudah tugas kita sebagai orang dewasa adalah menjaga mereka. Oleh karena tu pentingnya memberi pengertian kepada anak tentang adaptasi kebiasan baru melalui cara yang menyenangkan, salah satunya melalui terapi bermain. Permaianan edukatif sangat disenangi oleh anak, karena belajar lewat permaianan membuat anak tidak menyadari bahwa kegiatan tersebut adalah sedang belajar. Beberapa penelitian membuktikan bahwa rangsangan belajar lewat permaianan dapat meningkatkan kognitif, sikap dan perilaku anak.

\section{MASALAH}

Permasalahan yang dihadapi oleh mitra yaitu tentang bagaimana memberikan pengetahuan kepada anak-anak sekolah tentang gaya hidup sehat dan bersih selama masa pandemi sehingga anak-anak dapat menerapkannnya dalam keseharian. Solusi yang ditawarkan untuk menyelesaikan permasalahan adalah mengadakan kegiatan yang mengembangkan suatu teknik yang mampu meningkatkan budaya hidup sehat anak. Teknik yang akan dikembangkan adalah "terapi bermain berbasis literasi hidup sehat". Kegiatan ini sangat sesuai dengan kondisi lapangan dimana sekolah dan lingkungan masyarakat akan memasuki tahap new normal. Kegiatan ini dapat membantu dalam mengembangkan budaya hidup sehat dalam kehidupannya. Pengusul dan mitra telah melakukan diskusi untuk menangani permasalahan-permasalahan yang muncul. Untuk masalah penerapan penilaian, solusi yang disepakati adalah mengadakan program edukasi anak secara berkelanjutan melalui terapi bermain. Terapi bermain yang akan digunakan yaitu bermain ular tangga raksasa. Sasarannya adalah siswa Sekolah Dasar di wilayah Pringsewu khususnya Kecamatan Gadingrejo.

Sasaran dalam program pengabdian masyarakat ini adalah siswa dan siswi di SDN 5 Gadingrejo. Hal ini dikarenakan SDN 5 Gadingrejo telah melaksanakan 
pembelajaran tatap muka dengan jadwal masuk yang bergilir. Hanya dua kelas saja yang dijadwalkan melakukan pembelajaran tatap muka setiap harinya. Hal ini dilakukan sebagai antisipasi agar tidak terbentuk terlalu banyak kerumunan di satu tempat

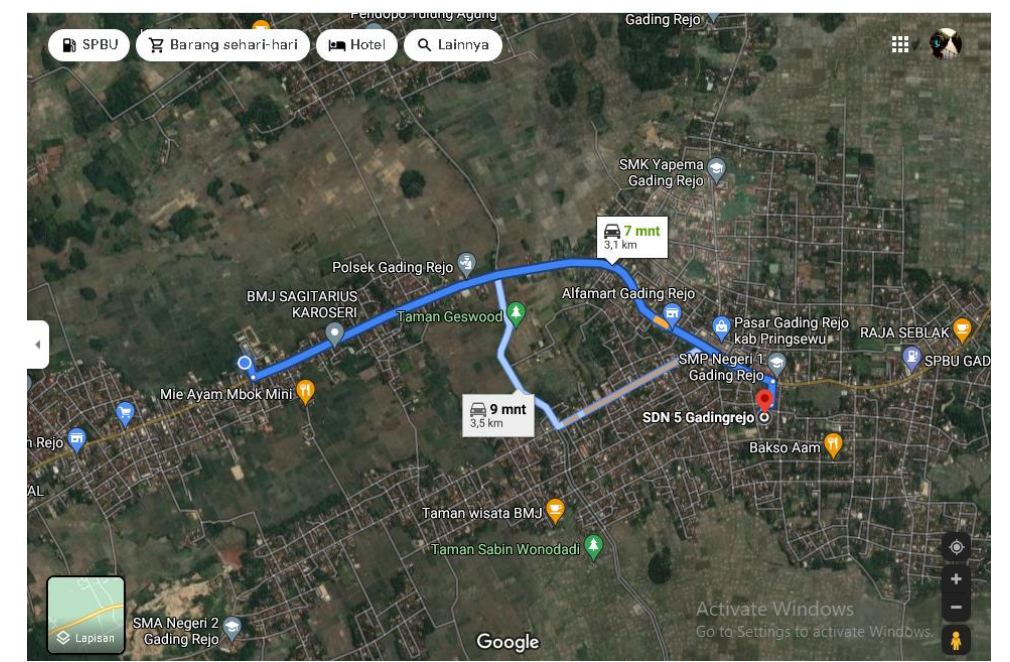

Gambar 1. Lokasi Pengabdian Masyarakat SDN 5 Gadingrejo

\section{METODE}

Metode pelaksanaan pada program pengabdian masyarakat ini merupakan sebuah rangkaian tahapan yang disusun secara sistematis yang diawali dengan tahap persiapan, diantaranya : observasi tempat pelaksanaan kegiatan, penawaran proposal kegiatan, konsultasi dengan guru wali kelas, menentukan permasalahan, menentukan topik dan metode penyuluhan, persiapan surat menyurat, alat dan bahan yang diperlukan.

Kegiatan ini dilaksanakan setelah semua perizinan dan persiapan sarana dan prasarana sudah siap. Kegiatan ini telah diusahakan untu dibuat menarik, agar anak-anak tertarik untuk mengikuti kegiatan dengan seksama. Metode yang digunakan dalam kegiatan ini adalah melalui terapi bermain ular tangga, bercerita pengalaman, dan diskusi serta tanya jawab.

Kegiatan ini ditulis berdasarkan rincian waktu yang telah dilaksanakan sesuai dengan rundown dan rencana yang telah ditentukan. Kegiatan dimulai pukul 08.00-11.00 WIB. Pukul 08.00-09.05 kegiatan dibuka oleh Tim pengsusul dan Kepala Sekolah. Kemudian pada pukul 08.05-08.30 langsung dilaksanakan pretest tentang pengetahuan mereka terkait $3 \mathrm{M}$ selama era New Normal Covid-19. Soal pretest ini berisi 10 butir pertanyaan dimana setiap butirnya memberikan pilihan benar atau salah. Peserta terlihat serius mengerjakannya dan mengerjakan sesuai kemampuan mereka tanpa contek kiri kanan. Setelah selesai melaksanakan pretest, pada pukul 08.30-09.30 acara dilanjut dengan mengajak anak-anak bermain ular tangga. Setiap bagian dari ular tangga tersebut terdapat materi pengetahuan terkait menerapan 3M selama era new normal covid-19.

Setelah peserta bermain ular tangga, acara dilanjutkan dengan mendengar cerita pengalaman sehari-hari mereka dalam menerapkan $3 \mathrm{M}$, selama sesi cerita pengalaman diselipkan juga edukasi dan diskusi untuk menambah pemahaman siswa. Sesi pun selesai pukul 10.00 kemudian dilanjutkan dengan 10.00-10.15 review materi yang sudah dijelaskan. Proses riview dijelaskan dengan bahasa yang lebih sederhana. Selain itu, untuk peserta yang berani menjawab ketika 
ditanya oleh narasumber diberi hadiah. Pukul 10.15-10.30 acara dilanjutkan dengan posttest. Soal posttest sama dengan soal pretest sebelumnya, peserta terlihat serius mengerjakan posttest yang diberikan. Dan akhirnya kegiatan pengabdian masyarakat ini resmi ditutup pukul 11.30 WIB. Sebelum semua bubar dan beranjak dari tempat, kegiatan diakhiri oleh sesi foto bersama dengan peserta.

\section{HASIL DAN PEMBAHASAN}

Pelakasanaan dalam kegiatan pengabdian masyarakat ini diadakan di SD Negeri 5 Gadingrejo pada tanggal 17 Februari 2021. Peserta yang megikuti merupakan siswa kelas 4 dan 5 yang berjumlah 45 siswa yang terdiri dari 15 siswa laki-laki dan 30 siswa perempuan.

Pada hari pelaksanaan, siswa beserta guru berkumpul di kelas. Kegiatan pertama yang dilakukan adalah mengenalkan kepada siswa tentang penyebaran virus dan penyakit yang berbahaya, pentingnya dan kapan harus melakukan tindakan 3M, terutama dalam mencegah penyakit yang disebabkan oleh coronavirus (Covid-19). Kemudian, siswa diajak untuk bermain ular tangga yang mana ular tangga tersebut berisi pengetahuan tentang penerapan $3 \mathrm{M}$ selama era new normal covid-19. Selanjutnya siswa bercerita tentang pengalaman mereka selama masa era new normal covid-19. Sebelum dan sesudah kegiatan pengabmas, siswa diberikan soal pretest dan posttest untuk melihat sejauh mana pemahaman siswa terkait 3M. Adapun hasil grafik kuesioner pretest dan posttest pada gambar 1.

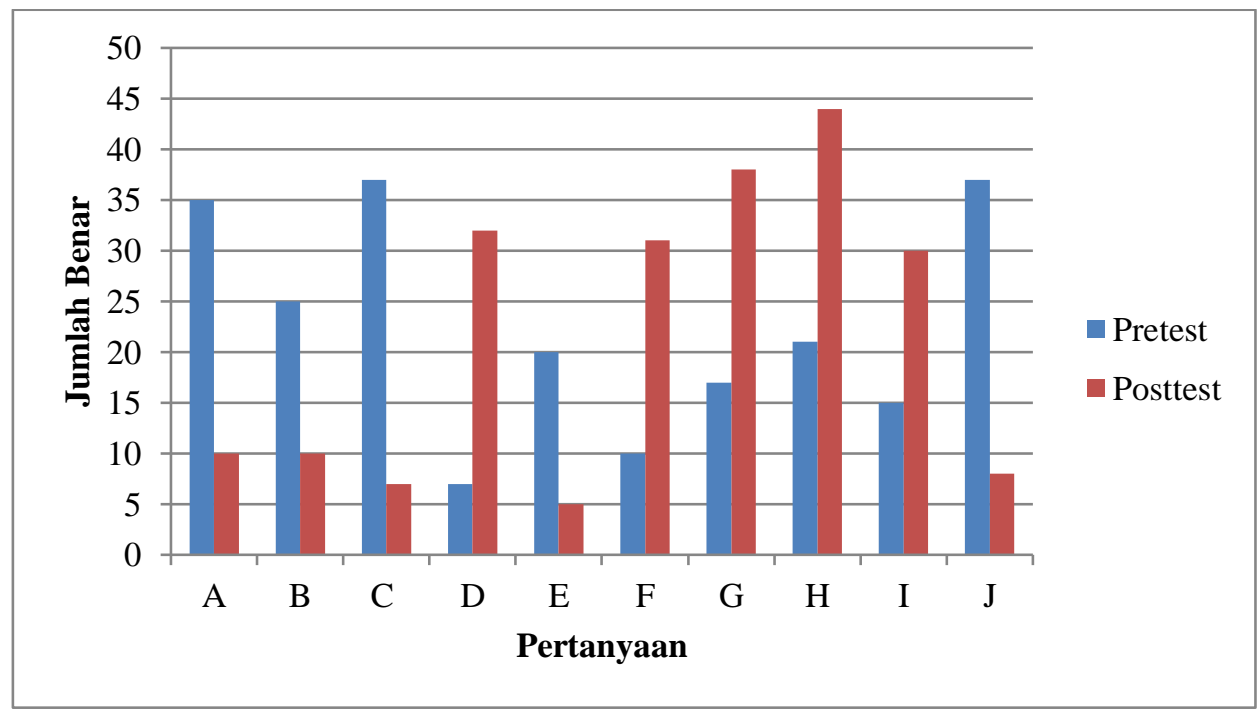

\section{Keterangan :}

\section{Gambar 1. Hasil Kuesioner Pretest dan Posttes}

A : COVID-19 adalah penyakit yang tidak berbahaya dan sama seperti flu biasa

B : Virus korona tidak akan menular pada saat berbicara

C : Orang yang bisa menularkan COVID-19 hanyalah yang memiliki gejala batuk dan pilek

D : Virus korona dapat bertahan hidup beberapa jam di luar tubuh manusia

E : Anak-anak tidak dapat tertular virus korona

F : Tanda dan gejala virus korona adalah batuk, tenggorokan sakit, hilang indra penciuman dan perasa 
G : Memakai masker, mencuci tangan dan menjaga jarak merupakan cara mencegah penularan virus korona

H : Makan makanan bergizi seperi sayur dan buah-buahan dapat meningkatkan daya tahan tubuh dan kesehatan

I : Virus korona dapat menular melalui berjabat tangan

$\mathrm{J}$ : Orang yang sehat tidak perlu memakai masker saat keluar rumah

Berdasarkan gambar 1 pada point pretes sebanyak 35 responden $(77,7 \%)$ beranggapan COVID-19 adalah penyakit yang tidak berbahaya dan sama seperti flu biasa, sebanyak 10 responden $(22,2 \%)$ sudah mengetahui tanda dan gejala virus korona adalah batuk, tenggorokan sakit, hilang indra penciuman dan perasa, sebanyak 17 responden $(37,7 \%)$ sudah mengetahui $3 \mathrm{M}$, dan sebanyak 21 responden $(46,6 \%)$ sudah mengetahui makan makanan bergizi seperi sayur dan buah-buahan dapat meningkatkan daya tahan tubuh dan kesehatan. Hal ini menunjukkan edukasi berbasis terapi bermain sangat diperlukan bagi anak-anak khususnya di SD Negeri 5 Gadingrejo dimana hal ini membantu pemerintah dalam mencegah penyebaran COVID-19. Menurut Amalia, et al (2018), edukasi adalah proses interaksi belajar seseorang dimana akan mengalami perubahan dari yang tidak tahu menjadi tahu akan sesuatu yang disampaikan oleh orang lain. Sehingga kegiatan penyuluhan terapi bermain ini tetap perlu dilaksanakan guna pencegahan timbulnya kesalahapahaman dan pengetahuan masyarakat khususnya anak-anak semakin baik. Kemudian pada point posttest, terdapat perubahan dimana sebanyak 10 responden (22,2\%) beranggapan COVID-19 adalah penyakit yang tidak berbahaya dan sama seperti flu biasa, sebanyak 31 responden $(68,8 \%)$ sudah mengetahui tanda dan gejala virus korona adalah batuk, tenggorokan sakit, hilang indra penciuman dan perasa, sebanyak 38 responden $(84,4 \%)$ sudah mengetahui $3 \mathrm{M}$, dan sebanyak 44 responden $(97,7 \%$ ) sudah mengetahui makan makanan bergizi seperi sayur dan buah-buahan dapat meningkatkan daya tahan tubuh dan kesehatan, yang berarti terdapat peningkatan pengetahuan masyarakat atas penyuluhan yang disampaikan sehingga indikator pencapaian dari kegiatan pengabdian ini berhasil. Hal ini sesuai dengan pengabdian Afandi (2015) bahwa implementasi media pembelajaran permainan ular tangga motivasi belajar siswa meningkat $66,7 \%$ pada aspek keaktifan belajar dan semangat belajar siswa, sedangkan aspek ketertarikan motivasi belajar siswa meningkat 70\%.

Permainan ular tangga merupakan permainan tradisional yang biasa dimainkan oleh anak-anak, tidak ada sumber yang jelas sejak kapan permainan ular tangga ditemukan. Konsep permainan ular tangga yaitu permainan dimainkan 2 anak atau lebih dengan melempar dadum yang terdiri dari beberapa kotak yang didalamnya ada gambar, dalam permainan ada gambar ular dan tangga, apabila dalam permainan mendapatkan tangga berarti naik sesuai dengan tangga tersebut, dan apabila mendapatkan ular maka dalam permainan tersebut peserta harus turun sesuai jalan ular tersebut. Peserta dinyatakan menang apabila peserta nyampai pada finis yang pertama. 

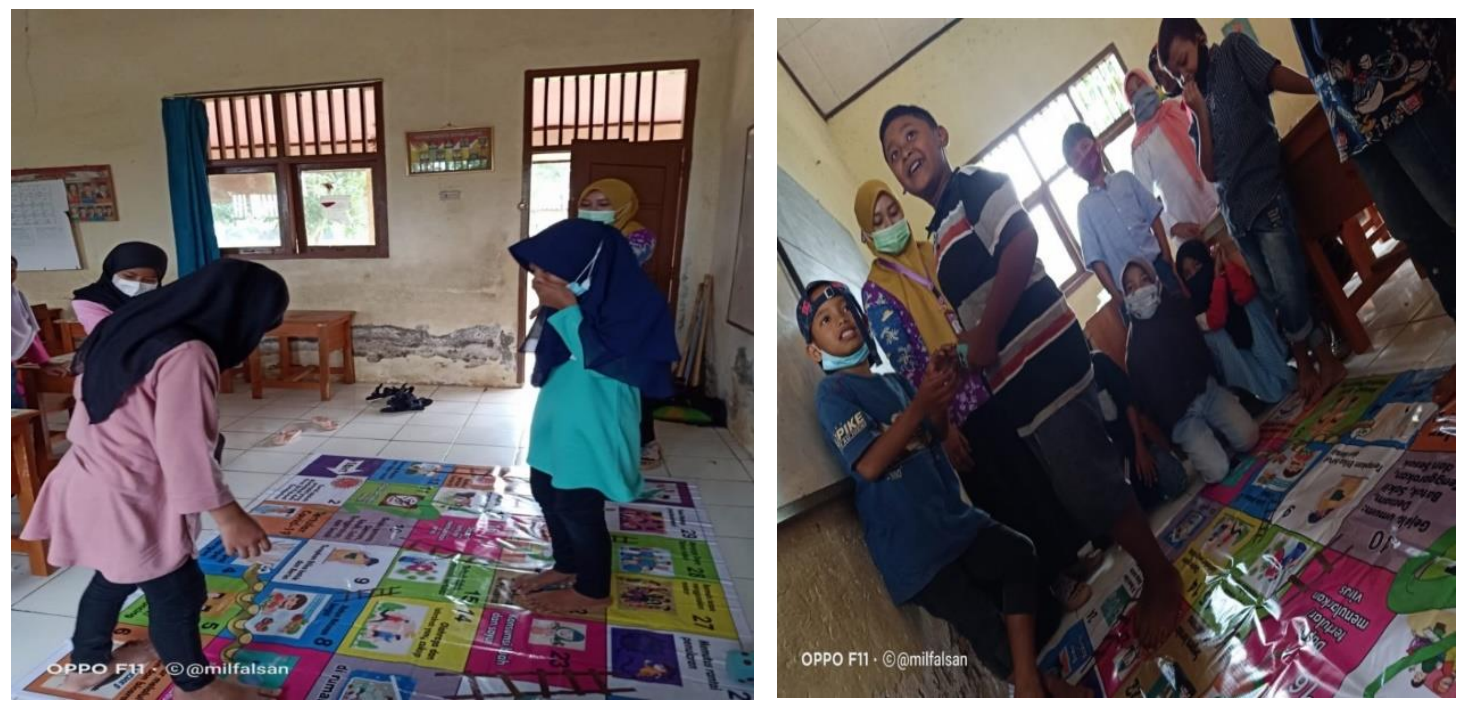

Gambar 2. Foto Kegiatan Bermain Ular Tangga

Permainan-permainan tradisional sederhana dapat menjadi sumber inspirasi dalam merancang sebuah media pembelajaran. Kita mengetahui bahwa permainan ular tangga adalah salah satu jenis permainan tradisional yang mendunia. Permainan ini tidak hanya berlaku di negara kita saja, tetapi juga di berbagai negara lain di dunia. Permainan ini merupakan jenis permainan kelompok, melibatkan beberapa orang dan tidak dapat digunakan secara individu. Secara psikologis, ular tangga terbukti dapat meningkatkan kemampuan anakanak untuk berinteraksi dengan kehidupan sosial. Berbeda dengan permainan berbasis media elektronik yang mengedepankan permainan individu, dimana anak-anak akan berkonsentrasi untuk sepenuhnya berinteraksi dengan media elektronik seperti komputer, video game atau play station. Para pakar psikologi menyebutkan, bahwa permainan tradisional cenderung lebih menguntungkan dibandingkan permainan melalui media elektronik (Nugrahani, 2007).

Ular Tangga ini dimodifikasi sehingga menjadi media permainan yang komunikatif dan mudah dimengerti, dengan visualisasi eye catching, atraktif dan menyenangkan untuk digunakan sebagai media belajar. Ular Tangga komunikatif disertai dengan gambar yang menarik dan full colour mutlak dibutuhkan dalam desain ular tangga ini. Dalam sebuah riset psikologi pendidikan disebutkan bahwa anak-anak lebih mudah memahami bahasa visual dibandingkan dengan bahasa verbal. Dengan demikian, sebuah media pembelajaran yang penuh dengan ilustrasi full colour yang komunikatif akan meningkatkan minat siswa untuk belajardan mengingat kembali pelajaran yang telah diberikan.

Pembelajaran berbasis permainan memiliki keunggulan karena membuka potensi untuk partisipasi penuh siswa dalam kegiatan dengan memicu perhatian mereka pada permainan, yang berarti mereka juga memperhatikan pelajaran (Nachiappan, Rahman, Andi, \& Zulkafaly; 2014). Permainan ular tangga dapat memfasilitasi siswa untuk belajar tentang penghitungan, kehidupan, interaksi dan sosialisasi. Di dalam permainan, secara implisit, para siswa dapat belajar tentang naik dan turun dalam hidup atau tentang kesenangan dan masalah. Tangga mewakili -ke atas hidup dan kegembiraan ", sedangkan keberadaan ular melambangkan" itu dalam hidup atau kesulitanll. Untuk membuat permainan ular tangga tidak hanya menyenangkan tetapi juga bermakna dalam pengajaran 
pembelajaran, maka permainan ular tangga dapat dimodifikasi denganvariasi instruksi yang sesuai dengan materi tertentu (Albab, 2014).

Para ahli psikologi anak menekankan pentingnya kebutuhan bermain bagi anak-anak. Bagi anak-anak, bermain merupakan kegiatan yang alami dan sangat berarti. Dengan bermain anak-anak mendapat kesempatan untuk mengadakan hubungan yang erat dengan orang dan lingkungan di sekitarnya. Permainan adalah sarana perkenalan serta arena pelatihan untuk berperilaku, berpikir secara simbolis dan pemecahan masalah. Di samping itu, permainan sangat penting untuk melatih otot-otot, ketrampilan fisik, keseimbangan, bekerja sama denganorang lain, belajar bercakap-cakap, persahabatan, dan latihan tata krama. Permainan juga akan memberikan kepuasan emosional yang diperolehnya dari keghidupan berkelompok, berprestasi, pengakuan dari orang lain, dan kebebasan. Dengan kata lain, permainan akan memberikan percepatan kepada anak-anak untuk melatih ketrampilan-ketrampilan fisik, ketrampilan-ketrampilan sosial, dan mendapat kepuasan emosional dan latihan intelektual (Hamalik, 2002).

Dalam rangka meningkatkan pengetahuan anak-anak di tingkat Sekolah Dasar, guru diharapkan untuk memanfaatkan taktik alat bantu yang mudah diterima (acceptable) untuk menggairahkan minat belajar siswa. Kondisi interaksi yang ideal antara guru dan murid apabila guru dengan sadar merencanakan setiap kegiatan secara sistematis dengan memanfaatkan segala sesuatunya guna kepentingan pengajaran. Menciptakan sebuah alat bantu tidak selalu sulit, halhal kecil di sekitar kita dapat menjadi inspirasi dalam membuat sebuah media pembelajaran dalam meningkatkan pegetahuan anak-anak.

\section{KESIMPULAN}

Permaianan edukatif sangat disenangi oleh anak, karena belajar lewat permaianan membuat anak tidak menyadari bahwa kegiatan tersebut adalah sedang belajar. Perbedaan pengetahuan anak sebelum dan sesudah kegiatan pendidikan kesehatan dengan media bermain ular tangga dan lebih berpengaruh dalam peningkatan pengetahuan dan sikap anak mengenai $3 \mathrm{M}$, karena ular tangga lebih banyak memberikan rangsangan terhadap anak dan sesuai dengan keinginan anak yakni bermain.

\section{DAFTAR PUSTAKA}

Afandi, R. (2015). Pengembangan media pembelajaran permainan ular tangga untuk meningkatkan motivasi belajar siswa dan hasil belajar IPS di sekolah dasar. JINoP (Jurnal Inovasi Pembelajaran), 1(1), 77-89.

Albab, U. (2014). The Effectiveness Of Snakes And Ladders Game To Improve Students'mastery Of Simple Past Tense In Constructing Recount Texts (A Quasi-Experimental Research of the Eighth Grade Students of SMP N 2 Demak in the Academic Year of 2013/2014). In ELT Forum: Journal of English Language Teaching (Vol. 3, No. 1).

Dinas Kesehatan Provinsi Lamapung. (2020). Lampung Tanggap Covid-19. Diambil dari https: / / dinkes.lampungprov.go.id/covid19/

Hamalik, O. (2000). Psikologi Belajar dan Mengajar. Bandung: Sinar Baru Algensindo.

Nachiappan, D. S., Rahman, N. A., Andi, H., \& Zulkafaly, F. M. (2014). Snake and Ladder Games in Cognition Development on Students with Learning Difficulties. Review of Arts and Humanities, 217-229. 
Nugrahani, R. (2007). Media pembelajaran berbasis visual berbentuk permainan ular tangga untuk meningkatkan kualitas belajar mengajar di sekolah dasar. Lembaran Ilmu Kependidikan, 36(1).

Pakpahan, A. K. (2020). Covid-19 Dan Implikasi Bagi Usaha Mikro, Kecil, Dan Menengah. Jurnal Ilmiah Hubungan Internasional, 59-64.

Peraturan Pemerintah Nomor 21. (2020). Pembatasan Sosial Berskala Besar Dalam Rangka Percepatan Penanganan Corona Virus Disease (COVID-19).

Saputra, N. M. A., \& Muharammah, N. W. (2020). Peran Layanan Bimbingan dan Konseling Sebagai Internalisasi Kemampuan Adaptasi Peserta Didik pada Era New Normal. In Prosiding Seminar Bimbingan dan Konseling: 75-79.

WHO. (2020). Coronavirus Desease (COVID-19) Outbreak Situation. Diambil dari https://www.who.int/emergencies/diseases/novel-coronavirus-2019

Zeegen, E. N., Yates, A. J., \& Jevsevar, D. S. (2020). After the COVID-19 pandemic: returning to normalcy or returning to a new normal?. The Journal of Arthroplasty, 35 (7), 7-41. 